\title{
ANALYSIS OF USING EFFICIENT LOGGING TOOLS AT PT. PURWA PERMAI IN CENTRAL KALIMANTAN
}

\author{
Sona Suhartana ${ }^{1,2}$ dan Yuniawati $^{1}$
}

\begin{abstract}
A high log demand that often exceeds its supply capability should be overcome by using appropriate logging tools. Numerous kinds and types of logging tools require a well planning in their utilization. Number of tools which are greater or fewer than what is actually needed can be disadvantageous for a company. In relevant to these aspects, a study was carried out at a timber estate in Central Kalimantan in 2007. The aim of the study was to find out an efficient number of tools used for logging in a timber estate. The analysis was based on the target and realization of the company's log production. The result revealed that: (1) Optimum number of logging tools depended on production target, i.e. 41 units of chainsaws for felling, 42 units of farm tractors for skidding, 9 units of loaders for loading and unloading, and 36 units of trucks for transportation; (2) Number of logging tools as obtained from all activities in the field was fewer than that from the analysis based on production target and realization. This condition indicated that number of logging tools used in the company was not yet efficient.
\end{abstract}

Keywords: High log demand, production target and realization, number of logging tools.

\section{INTRODUCTION}

Logging covers chain of activities that convert potential value of forest products (log and non-log) to actual value of products (wood and non-wood) (Nugroho, 2003). With the advancement of technology and increase in log demand, hence, the use of logging tools to achieve a production target at the company is required. A suitable consideration of choosing and using tool technically, economically, and ecologically is needed in logging activity (Haryanto, 1996; Suhartana et al., 2006).

To achieve an efficient logging, the company should solve a problem of choosing suitable tools with appropriate number using applied method to enforce an efficient and effective production of logging activities (Purnama and Basuki, 2003; Suhartana and Yuniawati, 2007; Suhartana et al., 2007). A proper number of tools is expected to achieve log production target and to eliminate

1 Forest Products Research and Development Center, Jalan Gunung Batu 5, PO Box 182, Bogor 16610 .

2 Corresponding author. E-mails: sona@forda-mof.org; ssuhartana@yahoo.com 
a company's loss. The use of greater number of tools can technically assure high log production, but it may not be economically acceptable. Conversely, fewer number of tools might bring about the log production below the target. In relevant, the aim of this study was to find out an efficient number of logging tools used in a timber estate based on the company's production target as well as production realization.

\section{MATERIALS AND METHODS}

\section{A. Location}

This study was conducted in July 2007 on a working area of a timber estate named PT. Purwa Permai. The estate/company was situated in the Forestry District of North Barito, under the Forest Service of Central Kalimantan Province (Figure 1).

Topography of the location was about 8-17\%, with the elevation of 92-175 $\mathrm{m}$ above sea level. Based on the Schmidt and Ferguson's classification, the type of climate there was categorized as "A" type with it monthly rainfall of 346 $\mathrm{mm}$. Vegetation of the area was dominated by gmelina without buttresses. The tree density was $680 \mathrm{stands} / \mathrm{ha}$ (for diameter of $10 \mathrm{~cm}$ and up).

The logging operation used chainsaw for felling and bucking (6 units), farm tractor for skidding (2 units), loader for loading and un-loading ( 3 units), and truck for transportation (6 units). Based on the decision of Minister of Forestry with the number: $931 / \mathrm{Kpts}-\mathrm{II} / 1999$ dated on 14-10-1999, this company established and started their operation in 1992/1993 with the area of 20,500 ha. It was predicted that 9,083 ha of the area, was the area of productive forests, and the rests area are conservation area and area for other use. In the Company's Annual Work Plan 2007, log production target was $267,333.04 \mathrm{~m}^{3} /$ year and average production realization was $146,932.48 \mathrm{~m}^{3}$ /year taken from $1,071.47 \mathrm{ha}$ area (PT Purwa Permai, 2007).

\section{B. Activities}

Activities of the study/research covered the collecting of primary and secondary data. Primary data were taken from field observations like the number of logging tools, working time and productivity. Secondary data such as annual allowable cut, forest area (ha), forest potential $\left(\mathrm{m}^{3} / \mathrm{ha}\right)$ and timber estate production data, were from the company's profile and from interviewing employees. 


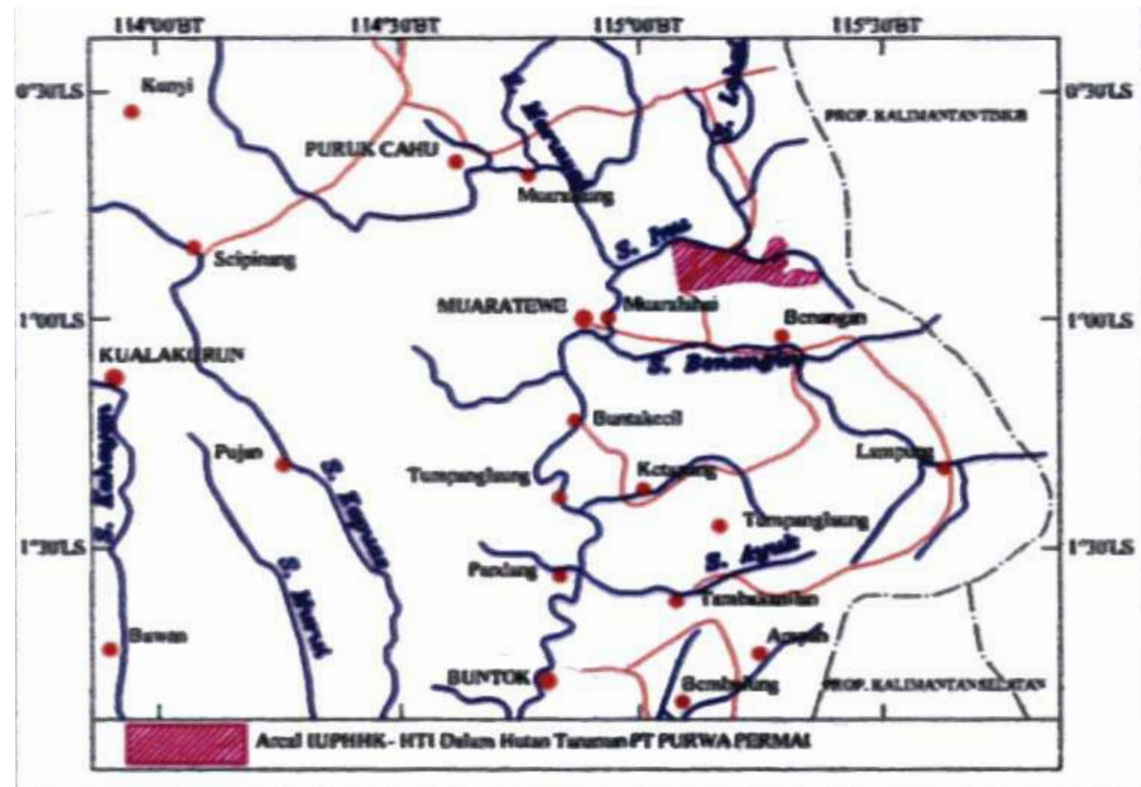

Figure 1. Study site map in PT Purwa Permai, Central Kalimantan

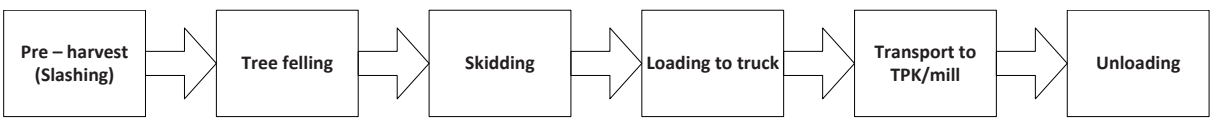

Figure 2. Flowchart-harvesting process in PT Purwa Permai, Central Kalimantan

\section{Data Analysis}

Data from field such as productivity, number of tools and cost of mechanical tools, were processed into tabulation form and calculated using the following formula:

1. Working productivity

$$
\mathrm{P}=\frac{\mathrm{V}}{\mathrm{T}} \text {, where : } \begin{gathered}
\mathrm{P}=\text { working productivity }\left(\mathrm{m}^{3} / \text { hour }\right) ; \mathrm{V}=\text { logged } \\
\text { volume }\left(\mathrm{m}^{3}\right) ; \text { and } \mathrm{T}=\text { working time (hour) }
\end{gathered}
$$


2. Number of felling tools required (Suhartana and Yuniawati, 2006):

a. Based on production target

$$
\mathrm{NCT}=\frac{\mathrm{PT}}{\text { Working productivity per day } \mathrm{x} \text { working time per year }}
$$

b. Based on production realization

$$
\begin{aligned}
\text { NCR }= & \frac{\mathrm{PR}}{\text { Working productivity per day } \mathrm{x} \text { working time per year }} \\
\text { where }: & \mathrm{NCT}=\text { number of chainsaws based on production target } \\
& \text { (units); NCR }=\text { number of chainsaws based on production } \\
& \text { realization (units); PT }=\text { production target }\left(\mathrm{m}^{3} /\right. \text { year); and } \\
& \mathrm{PR}=\text { production realization }\left(\mathrm{m}^{3} /\right. \text { year). }
\end{aligned}
$$

3. Number of mechanical tools (skidding, loading and un-loading, and transportation tools) required (Keputusan Menteri Kehutanan No. 428/ Kpts-II/2003):

a. Based on production target

$$
\begin{aligned}
& \mathrm{NT}=\frac{\mathrm{PT}}{12 \text { months } \mathrm{x} \text { working day per month } \mathrm{x} \text { trip per day } \mathrm{x} \text { TC }} \\
& \mathrm{NR}=\frac{\mathrm{PR}}{12 \text { months } \mathrm{x} \text { working day per month } \mathrm{x} \text { trip per day } \mathrm{x} \mathrm{TC}} \\
& \text { where }: \mathrm{NT}=\text { number of mechanical tools based on production } \\
& \text { target (unit); NR = number of mechanical tools based on }
\end{aligned}
$$

4. Cost of mechanical tools (FAO, 1992):

$$
\begin{aligned}
M T C & =\frac{E d+E i s+E i t+E t+E f+E o+E m+E w}{M T P} ; E d=\frac{P \times 0.9}{L h} ; E i s=\frac{P \times 0.6 \times 3 \%}{L y} ; \\
\text { Eit } & =\frac{P \times 0.6 \times 2 \%}{L y} ; E t=\frac{P \times 0.6 \times 18 \%}{L y} ; E f 1=0.20 \times \mathrm{HP} \times 0.54 \times \mathrm{FPr}
\end{aligned}
$$




\section{$\mathrm{Ef} 2=0.12 \times \mathrm{HP} \times \mathrm{FPr} ; \quad \mathrm{Em}=1.0 \times \mathrm{Ed} ; \quad \mathrm{Eo}=0.1 \times \mathrm{Ef}$}

where: $\mathrm{MTC}=$ cost of mechanical tools $\left(\mathrm{Rp} / \mathrm{m}^{3}\right) ; \mathrm{Ed}=$ depreciation expenses (Rp/hour); Eis = insurance expenses ( $\mathrm{Rp} /$ hour); Eit $=$ interest expenses (Rp/hour); Et $=$ tax expenses $(\mathrm{Rp} /$ hour); Ef = fuel expenses (Rp/hour); Ef1 : Ef for felling, skidding and loading-unloading; Ef2 = Ef for transportation; Eo $=$ oil/lubrication expenses $(\mathrm{Rp} /$ hour $) ; \mathrm{Em}=$ maintenance expenses (Rp/hour); $\mathrm{Ew}_{\mathrm{w}}=$ wage expenses $(\mathrm{Rp} / \mathrm{hour}) ; \mathrm{MTP}=$ productivity of mechanical tools ( $\mathrm{m}^{3} /$ hour); $\mathrm{P}=$ tool price $(\mathrm{Rp})$; $\mathrm{FPr}=$ fuel price $(\mathrm{Rp} /$ litre); $\mathrm{Lh}=$ working time of tools (hour); $\mathrm{Ly}=$ working time of tools (hour/year).

In data processing: 1) for productivity, it is analyzed using formula No 1 (in previous page) according to each of logging activities, therefore the productivity of each logging tools can be obtained; 2) based on aspect 1), further can be calculated the number of efficient tools that were analyzed by production target and production realization, and then compared with the number of tools operated in the field using formula No 2 and No 3; and for cost of mechanical tools, it is analyzed using formula No 4.

\section{RESULTS AND DISCUSSION}

\section{A. Working Productivity}

The working productivity of logging tools is presented in Table 1 and the figure of logging tools is presented in Appendix 1.

Table 1. Tool productivity ( $\mathrm{m}^{3} /$ hour)

\begin{tabular}{cllc}
\hline No. & Operational aspects & \multicolumn{1}{c}{$\begin{array}{c}\text { Tool's name and factory } \\
\text { specification }\end{array}$} & Productivity (m³/hour) \\
\hline 1. & Felling & Chainsaw Stihl 070 & 2.85 \\
2. & Skidding & Farm tractor MF440 & 3.75 \\
3. & Loading-unloading & Loader Caterpillar & 20.00 \\
4. & Transportation & Truck Mitsubishi PS100 & 1.50 \\
\hline
\end{tabular}


Based on Table 1, number of efficient tools taking into account production target and production realization can be calculated and then compared with number of tools operated in field. The result is presented in Table 2 and Figure 3.

Table 2 shows that number of tools operated in the field is fewer than those based on analysis results by production target as well as production realization. The differences regarding the number of tools on felling in production target and production realization are -35 and -16 units, respectively; skidding -40 and -21 units; loading-unloading -6 and -2 units; meanwhile transportation -34 and -14 units.

Table 2. Number of logging tools (units)

\begin{tabular}{|c|c|c|c|c|c|c|}
\hline \multirow{2}{*}{ No. } & \multirow{2}{*}{$\begin{array}{l}\text { Operational } \\
\text { aspects }\end{array}$} & \multirow{2}{*}{$\begin{array}{c}\text { Actual number } \\
\text { of tools used } \\
\text { in the field } \\
\text { (units) }\end{array}$} & \multicolumn{2}{|c|}{$\begin{array}{l}\text { Number of tools based on } \\
\text { analysis result using: (units) }\end{array}$} & \multicolumn{2}{|c|}{ Differences (units) } \\
\hline & & & $\begin{array}{c}\text { Production } \\
\text { target }\end{array}$ & $\begin{array}{c}\text { Production } \\
\text { realization }\end{array}$ & $\begin{array}{c}\text { Production } \\
\text { target }^{1)}\end{array}$ & $\begin{array}{l}\text { Production } \\
\text { realization }{ }^{2)}\end{array}$ \\
\hline 1. & Felling & 6 & 41 & 22 & -35 & -16 \\
\hline 2. & Skidding & 2 & 42 & 23 & -40 & -21 \\
\hline 3. & Loading-unloading & 3 & 9 & 5 & -6 & -2 \\
\hline 4. & Transportation & 6 & 36 & 20 & -34 & -14 \\
\hline
\end{tabular}

Remarks : 1) = Number of actual tools minus number of tools based on production target.

2) $=$ Number of actual tools minus number of tools based on production realization.

In loading and unloading aspects, the difference between actual number of tools, in the field and number of tools based on production target as well as on production realization was the smallest (in absolute figure), i.e. -6 and -2 , respectively (Table 2 ). This situation was caused by high productivity in that aspect $\left(20 \mathrm{~m}^{3}\right.$ /hour). In other words, fewer logging tools than they should be, as indicated by negative signs (Table 2 and Figure 4) indicated that the forest company was not efficient in the use of tools. Consequently, logging activities in that company had not yet reached the efficient condition. 


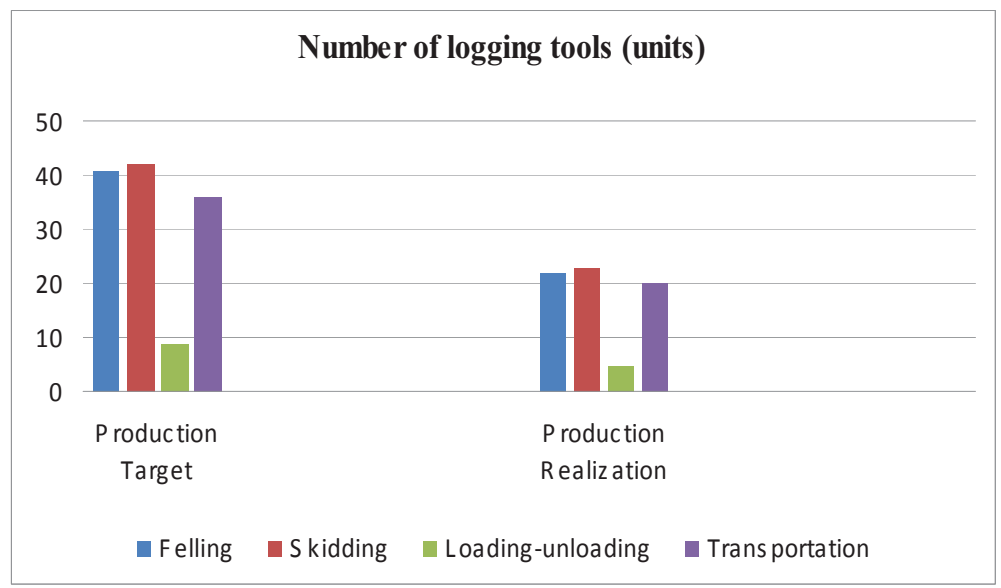

Figure 3. Number of logging tools (units)

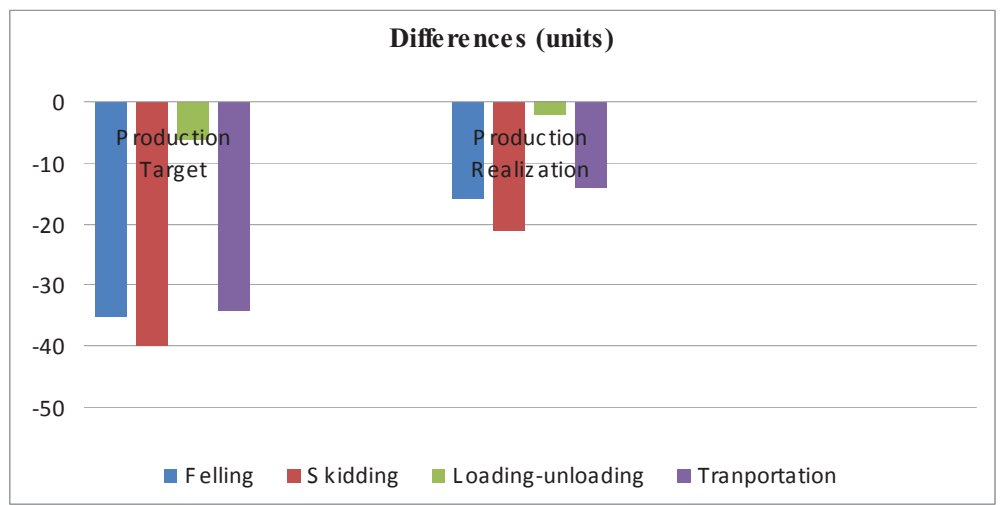

Figure 4. The differences in number of logging tools (units)

\section{B. Log Production}

By counting the actual number of logging tools (Table 2), then an amount of log production could be calculated by comparing it with production target and production realization. The elaborated amount of log production for each operational aspects is presented in Table 3. The table shows that the actual log production for all operational aspects in the field was significantly fewer than those based on production target as well as production realization. In brief, the use of fewer logging tools in the field brought about less log production. 
Table 3. The amount of log production for each operational aspect of logging tools

\begin{tabular}{|c|c|c|c|c|c|c|c|}
\hline \multirow[b]{2}{*}{ No } & \multirow[b]{2}{*}{$\begin{array}{l}\text { Operational } \\
\text { aspects }\end{array}$} & \multicolumn{2}{|c|}{ In the field } & \multicolumn{2}{|c|}{ Log production $\left(\mathrm{m}^{3} /\right.$ year $)$} & \multicolumn{2}{|c|}{$\begin{array}{c}\text { Number of logging tools } \\
\text { (units) }\end{array}$} \\
\hline & & $\begin{array}{c}\text { Actual log } \\
\text { production } \\
\left(\mathrm{m}^{3} / \text { year }\right)\end{array}$ & $\begin{array}{l}\text { Actual } \\
\text { number } \\
\text { of logging } \\
\text { tools (units) }\end{array}$ & $\begin{array}{c}\text { Based on } \\
\text { production } \\
\text { target } \\
\left(\mathrm{m}^{3} / \text { year }\right)\end{array}$ & $\begin{array}{l}\text { Based on } \\
\text { production } \\
\text { realization } \\
\left(\mathrm{m}^{3} / \text { year }\right)\end{array}$ & $\begin{array}{l}\text { Based on } \\
\text { production } \\
\text { target }\end{array}$ & $\begin{array}{l}\text { Based on } \\
\text { production } \\
\text { realization }\end{array}$ \\
\hline 1 & Felling & $39,398.4$ & 6 & $269,222.4$ & $144,460.8$ & 41 & 22 \\
\hline 2 & Skidding & $10,800.0$ & 2 & $226,800.0$ & $124,200.0$ & 42 & 23 \\
\hline 3 & $\begin{array}{l}\text { Loading and } \\
\text { unloading }\end{array}$ & $194,400.0$ & 3 & $583,200.0$ & $324,000.0$ & 9 & 5 \\
\hline \multirow[t]{2}{*}{4} & Transportation & $11,340.0$ & 6 & $68,040.0$ & $37,800.0$ & 36 & 20 \\
\hline & Total & $255,938.4$ & 17 & $1,147,262.4$ & $630,460.8$ & 128 & 70 \\
\hline
\end{tabular}

In total (Table 3), the amount of log production in the field $(255,938.4$ $\mathrm{m}^{3} /$ year) is less than those based on production target $\left(1,147,262.4 \mathrm{~m}^{3} /\right.$ year $)$ and based on production realization $\left(630,460.8 \mathrm{~m}^{3} /\right.$ year $)$. The differences for each operational aspects were consecutively $-229,824.0 \mathrm{~m}^{3} /$ year and $-105,062.4 \mathrm{~m}^{3}$ /year (felling); -216,000.0 $\mathrm{m}^{3}$ /year and $-113,400.0 \mathrm{~m}^{3} /$ year (skidding); - $388,800.0 \mathrm{~m}^{3}$ /year and $-129,600.0 \mathrm{~m}^{3}$ /year (loading-unloading); $-56,700.0 \mathrm{~m}^{3}$ /year and $-26,460.0 \mathrm{~m}^{3}$ /year (transportation).

Loading-unloading work brought out actual log production in the field greater than that based on the company's production target as well as production realization (Table 3 ). This situation was brought about by high loading-unloading productivity $\left(20 \mathrm{~m}^{3} /\right.$ hour $)$. Besides, it was also caused by longer working hours per day in loading-unloading work than those based on production target or production realization (Table 4).

If we look into performance of logging tools with respect to log production, especially based on production target, we should not feel worried about negative/positive sign (Table 2). This was brought about by well planned work that further improved log production.

\section{Production Time}

Using Tables 1, 2, and 3, production time could be calculated for each operational aspects of the logging tools (Table 4). 
Table 4. Production time (months) for each operational aspects of logging tools

\begin{tabular}{|c|c|c|c|c|c|c|c|}
\hline \multirow[b]{2}{*}{ No } & \multirow{2}{*}{$\begin{array}{l}\text { Operational } \\
\text { aspects }\end{array}$} & \multirow{2}{*}{$\begin{array}{c}\text { Actual } \\
\text { number of }\end{array}$} & \multicolumn{2}{|c|}{$\begin{array}{l}\text { Log production } \\
\left(\mathrm{m}^{3} / \text { year }\right)\end{array}$} & \multicolumn{3}{|c|}{ Production time (months) } \\
\hline & & & $\begin{array}{l}\text { Based on } \\
\text { production } \\
\text { target }\end{array}$ & $\begin{array}{l}\text { Based on } \\
\text { production } \\
\text { realization }\end{array}$ & $\begin{array}{l}\text { Actual time } \\
\text { in the field }\end{array}$ & $\begin{array}{l}\text { Based on } \\
\text { production } \\
\text { target }\end{array}$ & $\begin{array}{l}\text { Based on } \\
\text { production } \\
\text { realization }\end{array}$ \\
\hline 1 & Felling & 6 & $269,222.4$ & $144,460.8$ & 81.4 & 11.9 & 22.2 \\
\hline 2 & Skidding & 2 & $226,800.0$ & $124,200.0$ & 297.0 & 14.1 & 25.83 \\
\hline 3 & Loading-unloading & 3 & $583,200.0$ & $324,000.0$ & 16.5 & 5.5 & 9.9 \\
\hline 4 & Transportation & 6 & $68,040.0$ & $37,800.0$ & 282.89 & 47.15 & 84.87 \\
\hline & Total & 17 & $1,147,262.4$ & $630,460.8$ & 677.79 & 78.65 & 142.80 \\
\hline
\end{tabular}

Table 4 indicated that actual production time of logging tools in the field (677.79 months) was longer than those based on production target (78.65 months) as well as production realization (142.80 months). This situation was caused by fewer available logging tools (17 units) compared to those based on production target and production realization i.e. 128 and 70 units, respectively (Table 3).

\section{Machinery Cost}

Costs of logging tool were calculated based on productivity, depreciation, purchasing, and operation cost. The cost components of logging tools were presented on Table 5.

Table 5. Cost components of logging tools

\begin{tabular}{lrrrr}
\hline & \multicolumn{4}{c}{ Operational aspects } \\
\cline { 2 - 5 } \multicolumn{1}{c}{ Cost components } & Felling & Skidding & $\begin{array}{r}\text { Loading- } \\
\text { Unloading }\end{array}$ & $\begin{array}{c}\text { Transpor- } \\
\text { tation }\end{array}$ \\
\hline Price (Rp) per unit & $7,500,000$ & $350,000,000$ & $475,000,000$ & $170,000,000$ \\
Working time of tools (hours) & 1,000 & 10,000 & 10,000 & 15,000 \\
Working hours of tools (hour/year) & 1,000 & 1,000 & 1,000 & 1,500 \\
Insurance (\%/year) & 3 & 3 & 3 & 3 \\
Interest (\%/year) & 18 & 18 & 18 & 18 \\
Tax (\%/year) & 2 & 2 & 2 & 2 \\
Cost of gasoline fuel (Rp/litre) & 6,000 & - & - & - \\
Cost of diesel fuel (Rp/litre) & - & 6,000 & 6,000 & 6,000 \\
Wages of operators and assistants (Rp/day) & 96,000 & 80,000 & 90,000 & 35,000 \\
Working hour (hour/day) & 8 & 8 & 18 & 7 \\
Machine power (HP) & 15 & 82 & 138 & 100 \\
\hline
\end{tabular}


Table 5 was used for calculating machinery cost for each operational aspects of logging tools calculated (Table 6).

Table 6. Machinery cost of logging tools

\begin{tabular}{llcccccc}
\hline & & \multicolumn{3}{c}{ Number of logging tools (units) } & \multicolumn{3}{c}{ Machinery cost (Rp/hour) } \\
\cline { 3 - 8 } No & $\begin{array}{c}\text { Operational } \\
\text { aspects }\end{array}$ & $\begin{array}{c}\text { Actual } \\
\text { number in } \\
\text { the field }\end{array}$ & $\begin{array}{c}\text { Based on } \\
\text { production } \\
\text { target }\end{array}$ & $\begin{array}{c}\text { Based on } \\
\text { production } \\
\text { realization }\end{array}$ & $\begin{array}{c}\text { Actual } \\
\text { number in } \\
\text { the field }\end{array}$ & $\begin{array}{c}\text { Based on } \\
\text { production } \\
\text { target }\end{array}$ & $\begin{array}{c}\text { Based on } \\
\text { production } \\
\text { realization }\end{array}$ \\
\hline 1 & Felling & 6 & 41 & 22 & $223,362.0$ & $1,526,307.0$ & $818,994.0$ \\
2 & Skidding & 2 & 42 & 23 & $359,499.2$ & $7,549,483.2$ & $4,134,240.8$ \\
3 & Loading-unloading & 3 & 9 & 5 & $763,249.2$ & $2,289,747.6$ & $1,272,082.0$ \\
4 & Transportation & 6 & 36 & 20 & $721,440.0$ & $4,328,640.0$ & $2,404,800.0$ \\
\hline
\end{tabular}

Table 6 shows that machinery cost for each of the logging tools (operational aspects) in the field was fewer than those based on production target and production realization. This situation occurred due to fewer number of logging tools needed. Although the fewer logging tools caused the lower machinery costs, this situation brought about inefficiency in logging operations thereby lowering log production. This condition was disadvantageous for the forest company for not reaching production target. For the information, according to the Forest Company's Annual Work Plan in 2007, the company operated in $1,071.47$ ha area in that $\log$ production target was $267,333.04 \mathrm{~m}^{3} /$ year, while its production realization was $146,932.48 \mathrm{~m}^{3} /$ year.

\section{CONCLUSIONS}

1. Efficient operation of the Forest Company depended on number of logging tools based on log-production target, i.e. 41 units of chainsaws for felling operation, 42 units of farm tractors for skidding, 9 units of loaders for loading and unloading, and 36 units of trucks for transportation.

2. Actual number of logging tools operating in the field is fewer than it should be based on analysis of log production target as well as production realization. This situation indicated that operation and available number of logging tools in the field are not yet efficient.

3. Actual machinery cost of logging tools in the field is less than those based on log production target and log production realization. This situation is disadvantageous for the company implying that it does not yet achieve log production target. 


\section{ACKNOWLEDGMENT}

The authors highly appreciate Dr. Rufi'i Abdullah for reviewing and structuring this manuscript. Further appreciation is also conveyed to $\mathrm{Mr}$. Hari Setijono for his encouragement and supports to the authors in writing this manuscript.

\section{REFERENCES}

FAO. 1992. Cost control in forest harvesting and road construction. FAO forestry paper No.99. FAO of the UN. Rome.

PT. Purwa Permai. 2007. Rencana Karya Tahunan Tahun 2007. Palangkaraya.

Haryanto. 1996. Pemanenan Hasil Hutan Buku 2: Penebangan. Yayasan Pembina Fakultas Kehutanan. Universitas Gajah Mada. Yogyakarta.

Keputusan Menteri Kehutanan No.428/Kpts-II/2003 tentang Pedoman Perhitungan Kebutuhan Alat-Alat Berat. Tanggal 18 Desember 2003.

Nugroho, B. 2003. Kajian institusi pelibatan usaha kecil menengah industri pemanenan hutan untuk mendukung pengelolaan hutan produksi lestari. Disertasi Program Pasca Sarjana. Institut Pertanian Bogor. Bogor. Tidak diterbitkan.

Purnama, B. M and M. Basuki. 2003. Masalah penebangan liar dan perspektif pemerintah. PT. Inhutani II. Direktorat Pengembangan. Jakarta.

Suhartana, S., Dulsalam, and D. Tinambunan. 2006. Peningkatan produksi hasil hutan melalui implementasi pemanenan hutan berwawasan lingkungan. Prosiding Seminar Hasil Litbang Hasil Hutan, tanggal 30 Nopember 2005 di Bogor. Hlm. 65-77. Pusat Penelitian dan Pengembangan Hasil Hutan. Bogor.

Suhartana, S. and Yuniawati. 2006. Effisiensi penggunaan chainsaw pada kegiatan penebangan: studi kasus di PT. Surya Hutani Jaya, Kalimantan Timur. Jurnal Penelitian Hasil Hutan 24(1):63-76, Februari 2006. Pusat Penelitian dan Pengambangan Hasil Hutan. Bogor.

Suhartana, S. and Yuniawati. 2007. Penggunaan alat pemanenan kayu yang efisien: studi kasus di satu perusahaan hutan di Kalimantan Timur. Jurnal Wahana Foresta 1:1-12, Januari 2007. Fakultas Kehutanan, Universitas Lancang Kuning. Pekanbaru.

Suhartana, S., Yuniawati, and Rahmat. 2007. Penggunaan jumlah chainsaw yang tepat dan efisien pada penebangan: studi kasus di satu perusahaan hutan di Kalimantan Timur. Jurnal Rimba Kalimantan 12:62-66, Juni 2007. Fakultas Kehutanan, Universitas Mulawarman. Samarinda. 
APPENDIX. Logging tools

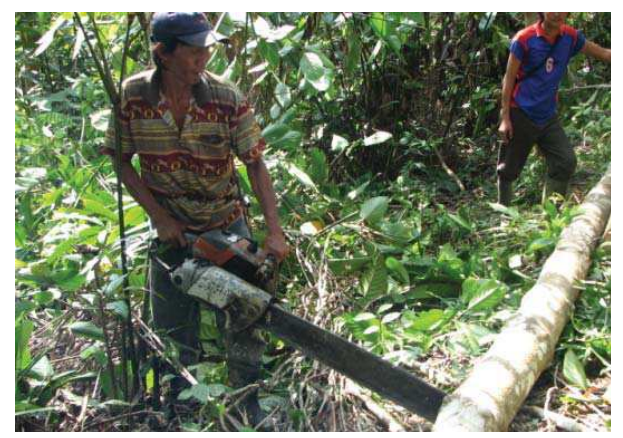

Figure 5. Chainsaw Stihl 070 for Felling and Bucking

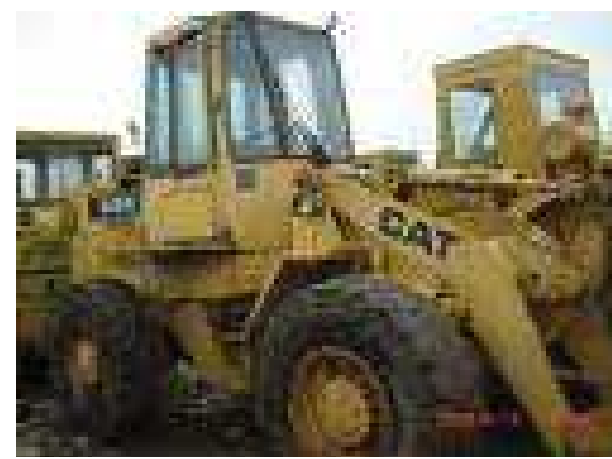

Figure 7. Loader Caterpillar

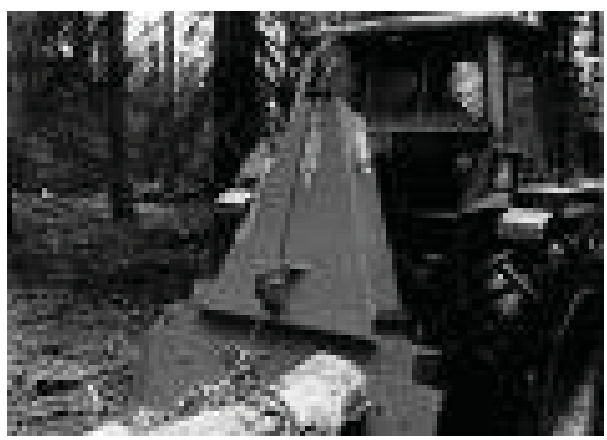

Figure 6. Farm tractor as a skidder

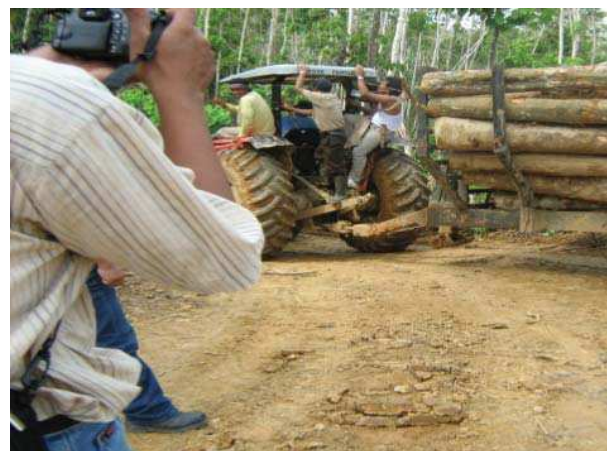

Figure 8. Truck Mitsubishi PS 100 